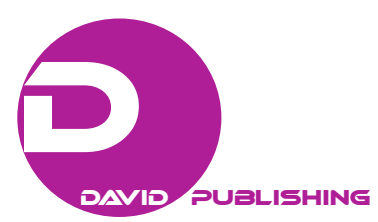

\title{
New Organization of the Power Industry in Poland as Seen From the European Perspective
}

\author{
Krzysztof Zamasz \\ The University of Dąbrowa Górnicza, Dąbrowa Górnicza, Poland
}

\begin{abstract}
The paper presents an analysis of the proposed changes in the organization of the Polish power industry in the context of European policy aimed at liberalization of the electricity market. The paper starts with a brief discussion of the outcomes of the last consolidation that was carried out by the government and the presentation of the biggest market players operating in the Polish power sector. Then the implications of the introduction of the internal European electricity markets for the Polish power producers are discussed. Potential consequences resulting from the completion of the projects of common interest are then commented, in particular an increase in the capacity of interconnectors linking Poland to neighboring countries from below 5\% to between $10 \%$ and $15 \%$. An analysis of the Polish power companies compared to their European competitors shows that with EBITDA (earnings before interest, taxes, depreciation and amortization) at a level of approximately $€ 2$ billion, the largest Polish power company (PGE) occupies a place in the lower sections of the top 20 European companies. The results of the other companies (TAURON, ENEA, and Energa) are negligible in the context of the European market. Based on the outcomes of this study, a conclusion is carried out that the further consolidation of the Polish power sector is required. The paper concludes that such consolidation should result in the creation of approximately three robust and relatively balanced entities, capable of competing in the common European electricity market and able to implement ambitious investment programs.
\end{abstract}

Keywords: electricity market, competition, power sector, consolidation, mergers and acquisitions, energy policy

\section{Introduction}

The current landscape of the Polish power industry is a natural consequence of many historical factors, including both the heritage of the previous political system (determining the industry's geographical, technical and first of all fuel structure) and the requirements imposed by the European Union (including in particular unbundling of electricity distribution, separation of transmission activities from market participants and the low-emission policy) (Kamiński, 2014). Obviously, a full analysis of the changes in the Polish power industry extends the scope and purposes of this paper. However, it makes sense to take a look at the industry's restructuring reform continuing from 2005 to 2008, which determined its current picture.

From 2005 to 2008, the government implemented three consecutive restructuring programs of the Polish power industry. These included "The Programme for the Realisation of the Ownership Policy of the Minister of the Treasury Concerning the Electroenergetic Sector” (adopted by the Council of Ministers on January 28, 2003)

Krzysztof Zamasz, Ph.D., The University of Dąbrowa Górnicza, Dąbrowa Górnicza, Poland.

Correspondence concerning this article should be addressed to Krzysztof Zamasz, Wyższa Szkoła Biznesu w Dąbrowie Górniczej, Cieplaka 1C, 41-300 Dąbrowa Górnicza, Poland. E-mail: krzysztof.zamasz@gmail.com. 
(Ministry of Treasury of the Republic of Poland, 2003), "Update of the Programme for the Realisation of the Ownership Policy of the Minister of the Treasury Concerning the Electroenergetic Sector" (adopted by the Council of Ministers on June 7, 2005), and the "Program for the Electric Energy Sector" (adopted by the Council of Ministers on March 27, 2006).

"Program for the Electric Energy Sector" (2006) developed by the Minister of Economy aimed at establishing economically robust companies capable of ensuring an adequate level of investments in generation capacity and in distribution and transmission infrastructure, thus ensuring reliability of electricity supply and sustainable growth of the power industry, respecting the country's obligations in the area of environmental protection. On top of that, cost reduction resulting from economies of scale and synergy effect was expected (Ministry of Economy of the Republic of Poland, 2006; Kamiński, 2014). The program assumed the creation of the following vertically integrated power groups:

- establishment of Polska Grupa Energetyczna (PGE), constituting a basis for achieving the assumed objectives and being a leading energy group in Poland and the Central Europe. PGE will be formed from the Bełchatów-Opole-Turów (BOT) holding, Dolna Odra Power Plants, assets remaining after separating the transmission system operator together with property out of Polskie Sieci Elektroenergetyczne S.A. (PSE S.A.), and finally companies from the so-called distribution groups L2, L5, and Rzeszowski Zakład Energetyczny (currently PGE S.A. Capital Group);

- consolidation of Południowy Koncern Energetyczny with distribution companies ENION and ENERGIA-PRO and with Stalowa Wola Power Plant (currently TAURON Polska Energia S.A. Capital Group) (Ministry of Economy of the Republic of Poland, 2006).

The following effects of the above changes (and of the unbundling process) were expected: (i) formation of robust, vertically integrated power companies modeled on European power companies; (ii) development of the electric power market; and (iii) universal and non-discriminatory access to transmission and distribution services through establishing independent grid operators (Ministry of Economy of the Republic of Poland, 2006).

Furthermore, the following moves were to be considered:

- privatization or consolidation of ENEA, Kozienice Power Plant, and Bogdanka Mine, in a manner determined by the Ministry of the Treasury;

- privatization or consolidation of ENERGA and ZE Ostrołęka in a manner determined by the Ministry of the Treasury (Ministry of Economy of the Republic of Poland, 2006).

The consolidation of ENEA with Kozienice Power Plant and Bogdanka (a hard coal mine) was carried out partially, without including Lubelski Wegiel (LW) Bogdanka. Eventually LW Bogdanka was privatized on the Warsaw stock exchange. Currently LW Bogdanka (securing most hard coal supplies to ENEA and Energa) is controlled by open pension funds (OFEs).

As a result of the consolidation, four vertically integrated power groups were formed:

- PGE S.A. Capital Group;

- TAURON Polska Energia S.A. Capital Group;

- ENEA S.A. Capital Group;

- ENERGA S.A. Capital Group.

Each of them is briefly described in the next section.

As regards the electricity market in Poland, it is currently a national market by nature. The throughput of interconnection points (i.e., interfaces with power systems of neighboring countries) is so low that wholesale 
electricity prices in Poland continue to be different than that in neighboring countries.

In 2014, the price of electricity in Poland was approximately 25\% higher than that in the neighboring markets of Germany, Czech Republic, Slovakia, Denmark, and Sweden. The difference resulted inter alia from considerable shares of renewable energy sources in those markets (in 2014, prices in Germany fell by $14 \%$ year-on-year; in Sweden, due to the country's favorable hydrological situation, prices fell by as much as $20 \%$ year-on-year) (Polska Grupa Energetyczna S.A., 2014) (Table 1).

Table 1

Comparison of Average Electricity Prices (PLN/MWh) in Poland and in Neighboring EU Countries

\begin{tabular}{ll}
\hline EU country & Average price of electricity (PLN/MWh) \\
\hline Poland & $\mathbf{1 8 4 . 1 5}$ \\
Germany & 136.97 \\
Czech Republic & 137.80 \\
Slovakia & 137.80 \\
Lithuania & 209.59 \\
Latvia & 209.55 \\
Estonia & 157.20 \\
Finland & 150.62 \\
Sweden & 133.44 \\
Denmark & 131.30 \\
\hline
\end{tabular}

Source: Polska Grupa Energetyczna S.A. (2014).

The above situation leads to a radical change in trans-border energy transactions. In 2014, electricity import grew by approx. $72 \%$ year-on-year, from an exporter Poland changed into an importer, as the following Figure 1 illustrates.

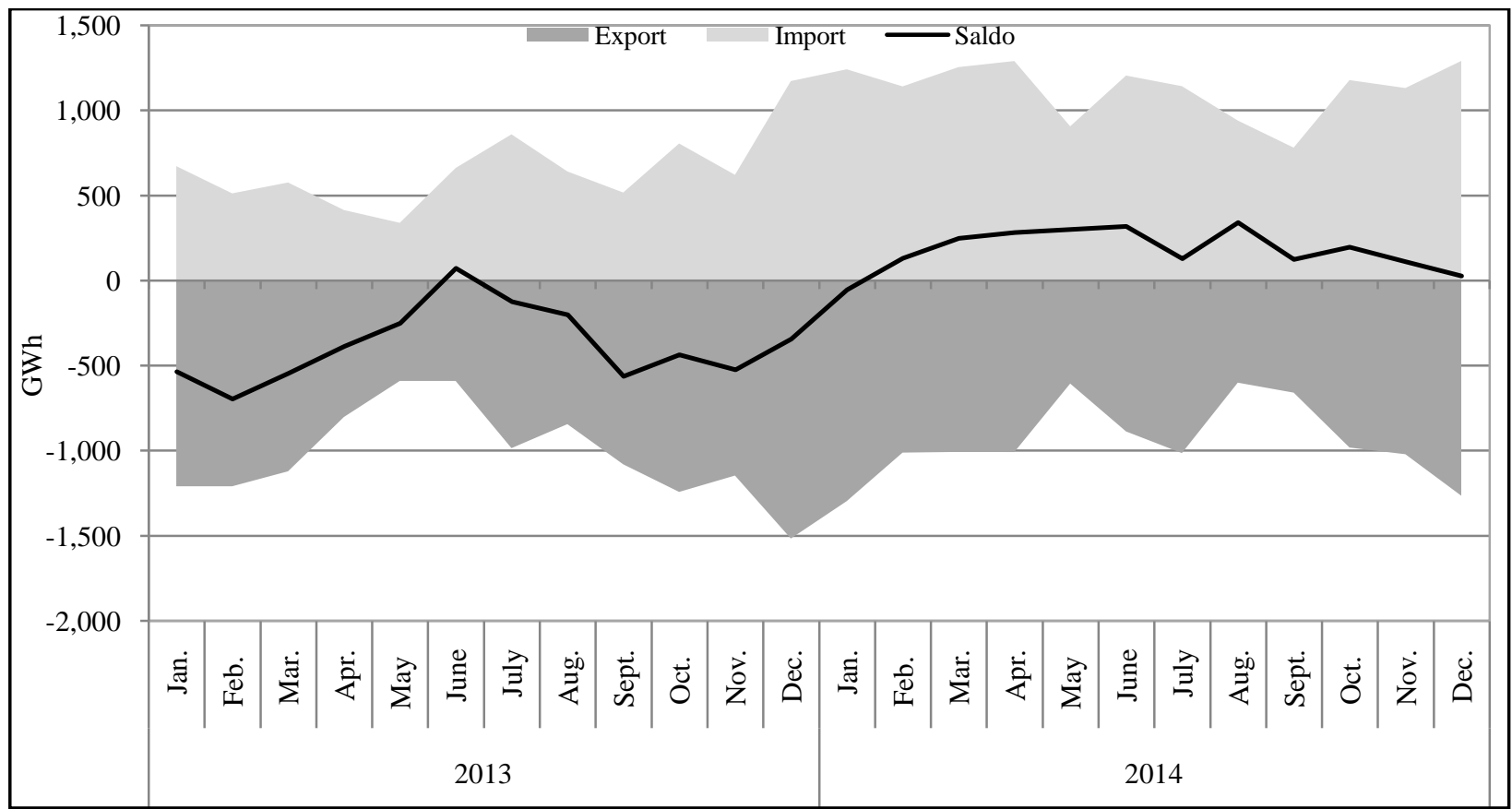

Figure 1. Monthly import, export and the balance of foreign exchange of electricity in 2013 and 2014. Source: Polska Grupa Energetyczna S.A. (2014). 
A number of conclusions follow from the above information. First of all, in some of the neighboring European countries, markets of a regional (i.e., trans-national) character have been actually created (Germany, Czech Republic, Slovakia, Denmark, and Sweden) ${ }^{1}$ (European Network of Transmission System Operators for Electricity [ENTSO-E], 2014). Uniform energy prices in those markets are the ultimate proof for that assumption. Second, together with the development of interconnections with Poland, strong pressure on Polish prices will appear and Polish energy groups will have to compete with other European electricity producers. Simultaneously, the European level of wholesale energy prices is considerably lower than the Polish prices, which will be a major challenge for domestic companies in the case of greater opening of the Polish market to energy imports. Moreover, a number of papers indicate that one of the key directions for improving energy market efficiency is to use energy transmission potential from Sweden (enjoying a considerable share of cost-efficient hydroelectric power plants) to Poland (Böckers, Haucap, \& Heimeshoff, 2013). The markets of the "new" EU are also a natural development direction for major electricity producers from the "old" EU (Domanico, 2007) and the main obstacle to such expansion is insufficient (at least for now) capacity of interconnections.

In this context, the aim of the paper is to analyze the Polish power sector and to answer the question whether the Polish power industry needs further consolidation and reorganization. In order to reply this question, first, the companies under consideration are presented and their economic position is discussed. Then European policy for the electricity market is discussed. Finally, Polish power companies are compared to the European companies. The paper ends with conclusions and policy recommendations.

\section{Key Power Companies Operating in Poland}

\section{Polish Energy Group (PGE)}

PGE is the largest power group formed as a result of the consolidation process. At the same time, PGE is the largest producer of electricity in Poland and the only major power group owning generation sources fired with brown coal (including Bełchatów, Poland's largest utility power plant (5.3 GW) and Turów (1.9 GW)).

Due to the specific nature of this fuel (low calorific value translating into very high transportation cost), PGE also owns open-pit brown coal mines located close to its power plants. Furthermore, PGE operates two large utility power plants fired with hard coal (Opole-1.5 GW and Dolna Odra-1.7 GW), as well as a number of major combined heat and power plants (Bydgoszcz, Gorzów, Lublin Wrotków, Rzeszów, Kielce, and Zgierz). PGE also owns a number of renewable sources (hydroelectric and wind power plants). PGE also plays a key role in the nuclear power plant construction project (70\% shares in PGE EJ1 sp. z o.o., an SPV in charge of the project). However, the nuclear project is currently at a very early stage.

As of 2013, PGE's share in the electricity generation market in Poland was approximately $39.3 \%{ }^{2}$ (Energy Regulatory Office, 2014), more than double the share of the second-biggest Polish electricity producer (TAURON Polska Energia S.A.-13.6\%).

With a significant share of power generation coming from sources fired with brown coal and given the low prices of $\mathrm{CO}_{2}$ emissions (Polska Grupa Energetyczna S.A., 2014), PGE enjoys a significant competitive advantage against its competitors generating electricity from hard coal or gas (Agencja Rynku Energii S.A.,

\footnotetext{
1 These countries partially belong to the regional market of the Baltic Sea area (Germany, Denmark, and Sweden) and the regional market of Continental Central East (Germany, Czech Republic, and Slovakia).

2 The figure refers to the share in the volume of electricity fed into the grid in 2013.
} 
2013). However, bearing in mind high emissions caused by brown coal, in the long term, PGE may be exposed to significant regulatory risks related to the cost of $\mathrm{CO}_{2}$ emissions.

PGE's advantage over its competitors results first of all from lower unit costs of electricity generation from brown coal, as compared to hard coal and gas. In 2013, the technical cost of generating electricity from brown coal was PLN 135/MWh (average figure for the entire industry in Poland), as compared to PLN 199/MWh for hard coal and PLN 372/MWh for gas (Agencja Rynku Energii S.A., 2014). Given the fuel advantage, PGE dominates the Polish generation market in two ways: Firstly, it has the largest share in installed power and in the volume of electricity sold to the grid; secondly, its generation assets have the highest cost efficiency.

The above circumstances make PGE more financially powerful than the other power groups. PGE is the only major integrated energy group for which power generation delivers a significant share of EBITDA (earnings before interest, taxes, depreciation and amortization) (PLN 4.21 billion in 2013, accounting for approx. 53\% of the capital group's EBITDA in 2013).

The PGE Group is also in the distribution business (which is separate from the transmission business, currently carried out by a company named PSE S.A., independent from other power sector companies and fully owned by the Treasury). PGE carries out distribution activities in central and eastern Poland, excluding Warsaw metropolitan area. PGE's share in the national distribution network is approx. 25\% (approx. $31.3 \mathrm{TWh}$ of electricity supplied to end users). The relatively small share in the electricity distribution volume coupled with considerable length of transmission lines (approx. 281 thousand kilometers) and a high number of connection points all result from the fact that PGE's operations are carried out in areas where the rate of urban and industrial development has been rather low, particularly in comparison to the south-western part of Poland.

The distribution business ensures stabilization of the other business segments (generation and trading). The foregoing results from the specific nature of the distribution business. Bearing in mind very high barriers to entry caused by the need to construct distribution infrastructure, the distribution business is a form of natural monopoly. Given the monopoly position of the distributor (in its geographical area), revenues from these operations are subject to regulatory limitations. Rates are calculated by distribution companies in accordance with legal regulations and must be subsequently approved by the President of the Energy Regulatory Office, ensuring a specified rate of return.

In the case of PGE, owing to its powerful and cost-efficient generation business (enjoying a favorable fuel structure and low costs of $\mathrm{CO}_{2}$ emissions), the importance of the distribution business is relatively smaller (approx. 28\% of the entire capital group's EBITDA in 2013) than for the other power groups.

Another element in PGE's value chain is trading. Despite a rapid growth of the TPA (third-party access) segment, in the case of vertically integrated groups, the position of the electricity seller is traditionally linked to the area occupied by the distribution system operator (so-called incumbent seller) (Energy Regulatory Office, 2014).

The maximum level of electricity prices is subject to regulatory limitations in the case of private consumers. Corporate consumers buy electricity on market terms. Very strong competition, visible in particular in the market of large industrial consumers, has led to major reductions of margins in this particular business. In 2013, PGE's retail sales of electricity amounted to 31.9 TWh (approx. 26.2\% of the total market volume), which gave PLN 0.29 billion in EBITDA (approx. 4\% of the entire capital group's EBITDA in 2013). 
The above-described competitive position of PGE allowed the group to achieve financial results above the industry average. In 2013, the group's revenues amounted to PLN 30.1 billion, with EBITDA of PLN 8.0 billion (EBITDA margin: 26.6\%) and net profit of PLN 4.1 billion (margin: 13.7\%).

A challenge, faced by PGE and by the other energy groups as well, is the implementation of investment plans, in the area of both generation and distribution. Capital expenditures planned by PGE for the years 2014 to 2020 amount to approx. PLN 50 billion, 15.2 billion of which is to be spent on new generation capacity (including renewables and preparatory works for the nuclear power plant). The balance of the investment budget is allocated for modernization and replacement projects in the power generation area and for the distribution business. Due to the relatively early stage of the nuclear project, it is not possible to present reliable figures showing possible costs of that investment. However, one can make a conservative assumption that the figure will be at least close to the entire value of the 2014-2020 investment program.

PGE shares are quoted on the Warsaw stock exchange. The company's capitalization in March 2015 amounted to approx. PLN 37.5 billion.

\section{TAURON Polish Energy (TAURON Polska Energia S.A.)}

TAURON Group, headed by TAURON Polska Energia S.A., is another entity formed through vertical consolidation of the power industry.

TAURON operates first of all in south-western Poland, i.e., in a part of the country with one of the highest rates of urban and industrial development. As of March 2015, TAURON—as the only major energy group - is involved in hard coal extraction (PGE owns only brown coal open-pit mines). In 2013, mines owned by TAURON Wydobycie catered for approx. 35\% of the TAURON's demand.

TAURON is the second-largest electricity producer in Poland, after PGE. In 2013, it generated 19.3 TWh of electricity, corresponding to a market share of $13.6 \%$. TAURON Group's generation assets are mostly based on hard coal. TAURON Group includes such power plants as Jaworzno III (1.3 GW), Łaziska (1.1 GW), Łagisza (1.0 GW), Siersza (0.7 GW), Stalowa Wola (0.3 GW), Jaworzno II (0.24 GW), and Blachownia (0.16 GW), as well as a number of combined heat and power plants (Katowice, Tychy, Bielsko-Biała, and Kamienna Góra). TAURON is also in possession of renewable energy sources (hydroelectricity and wind). Furthermore, TAURON holds 10\% share in PGE's SPV (PGE EJ1) established for the purpose of the nuclear power plant project.

For reasons explained above (low cost of electricity generation from brown coal coupled with low cost of $\mathrm{CO}_{2}$ emissions), the fact that most of TAURON's generation assets are fired with hard coal has resulted in a significant cost imbalance in relation to the largest energy producer in Poland (PGE). In 2013, TAURON's generation business yielded a marginal EBITDA (PLN 0.03 billion or just 1\% of the entire TAURON Group's EBITDA in 2013). A significant change from 2011 needs to be noted-back then the generation business yielded approx. 34\% of the Group's EBITDA (i.e., approx. PLN 1.05 billion out of 3.06 billion). The above figures quite clearly illustrate changes that have taken place on the electricity generation market in Poland over the last couple of years.

Electricity distribution is TAURON's key area of operation. Having purchased geographically complementary distribution assets (former Górnośląski Zakład Energetyczny) (Energy Regulatory Office, 2012) from Vattenfall in 2011, TAURON became the largest electricity distributor in Poland. In 2013 TAURON supplied 47.9 TWh of electricity, accounting for approx. 39\% of the entire distribution market in Poland. 
However, it needs to be remembered that electricity distribution is a natural monopoly, which is why nationwide market shares are used for comparative purposes, rather than for assessing companies' competitive positions. Advantageous geographical location of distribution assets (highly urbanized and industrialized south-western part of the country) allows TAURON to enjoy such a large market share, despite a shorter length of distribution lines (approx. 260 thousand kilometers as compared to approx. 281 thousand kilometers owned by PGE). The foregoing has a positive effect on the distribution business's EBITDA, which amounted to approx. PLN 2.21 billion in 2013, representing approx. 60\% of the entire Group's EBITDA. Attention needs to be drawn to a remarkable growth of the distribution business EBITDA from 2011 (i.e., from before take-over of Vattenfall's distribution assets). In 2011, distribution yielded EBITDA of PLN 1.3 billion or approx. 42\% of the entire Group's EBITDA.

One consequence of the strong position in the distribution market is TAURON's significant share in the electricity sales market. In 2013, the sales volume was 44.7 TWh, corresponding to a market share of $36.7 \%$. EBITDA from sales amounted to PLN 0.9 billion or $25 \%$ of the entire group's EBITDA.

From the perspective of the entire TAURON group, revenues in 2013 amounted to PLN 19.1 billion, with EBITDA at a level of PLN 3.7 billion (EBITDA margin: 19.1\%) and net profit of PLN 1.3 billion (margin: $7.0 \%)$.

Capital expenditures planned for the period from 2014 to 2020 amount to approx. PLN 26 billion. Key investment projects include construction of a $0.9 \mathrm{GW}$ new hard coal unit in Jaworzno Power Plant.

As of March 2015, TAURON's market capitalization was approx. PLN 8.15 billion.

\section{ENEA S.A.}

ENEA was formed through consolidation of power companies operating in the north-western part of Poland and additionally Kozienice Power Plant (a major commercial power plant fired with hard coal with rated output of $2.8 \mathrm{GW}$ ). In 2011, the ENEA Group additionally acquired Białystok Combined Heat and Power Plant. Similarly to the other power groups, ENEA also owns a number of renewable energy sources (hydroelectricity and wind).

As mentioned above, contrary to the original intentions of the government, the ENEA Group does not include Bogdanka hard coal mine (Ministry of Economy of the Republic of Poland, 2006; Supreme Chamber of Control, 2009), for which Kozienice Power Plant is the largest sales market. As a result, the ENEA Group does not possess any extraction operations that would ensure its own fuel supply.

With electricity production at a level of $11.3 \mathrm{TWh}$, ENEA holds approx. 8\% of the market. In 2013, the generation business yielded EBITDA of PLN 0.56 billion or approx. 34\% of the entire Group's EBITDA in that year.

ENEA holds approx. 14\% of the national distribution market (17.2 TWh). Like the case of TAURON, distribution accounts for a major share of ENEA's EBITDA, stabilizing the results from generation and trading. The length of power lines owned by ENEA is approx. 130 thousand kilometers and is thus considerably shorter than those of the other major power groups. In 2013, ENEA's distribution business generated EBITDA of PLN 0.88 billion, representing approx. $53 \%$ of the entire Group's EBITDA.

Electricity sales at a level of 14.9 TWh ensured a 12.2\% market share. In 2013, EBITDA from this area of operation amounted to PLN 0.25 billion (15\% of the entire Group's EBITDA). As compared to the other energy groups, the share of EBITDA generated by the sales area is the highest. 
From the perspective of the entire ENEA group, revenues in 2013 amounted to PLN 9.1 billion, with EBITDA at a level of PLN 1.65 billion (EBITDA margin: 18.1\%) and net profit of PLN 0.7 billion (margin: $7.8 \%$ ).

Unlike the groups described above, ENEA is burdened with an extensive investment program, with investments worth approx. PLN 15 billion being planned for the years from 2014 to 2020. Key investments include the construction of Europe's largest coal-fired unit with a capacity exceeding $1 \mathrm{GW}$.

ENEA shares are quoted on the Warsaw stock exchange. The company's capitalization in March 2015 amounted to approx. PLN 7.3 billion.

\section{Energa}

Energa was formed through consolidation of eight distribution companies owned by the Treasury, operating in northern and central Poland. Additionally, Energa features Ostrołęa Power Plant (installed power: $0.6 \mathrm{GW})$.

Out of the four major Polish energy groups, Energa is the least represented in the generation business. With production at a level of $3.7 \mathrm{TWh}$, Energa holds approx. 2.5\% of the market. As of 2013, the generation business yielded PLN 0.22 billion of Energa's EBITDA, or approx. 11\% of the entire Group's EBITDA.

Energa's operations concentrate on the distribution business. The volume of electricity supplies amounted to $20.1 \mathrm{TWh}$, which translates into a share of approx. 16.4\% in the Polish market and gives Energa the 3rd place among the country's major power groups. The length of Energa's distribution lines is approx. 194 thousand kilometers. The importance of the distribution business for the Energa Group is illustrated by the percentage of the Group's EBITDA generated from this particular area of operation. In 2013, distribution brought PLN 1.56 billion of the Group's EBITDA or $80 \%$ of the total figure.

For reasons explained above, the relatively strong position of Energa in the distribution market has a significant effect on the trading business. With a sales volume of 20.5 TWh (16.8\% of the market), also in this business area, Energa occupies the 3rd place among major, vertically integrated energy groups in Poland.

From the perspective of the entire Energa Group, revenues in 2013 amounted to PLN 11.4 billion, with EBITDA at a level of PLN 1.96 billion (EBITDA margin: 17.2\%) and net profit of PLN 0.7 billion (margin: $6.5 \%)$.

Similarly to the other energy groups, Energa has planned an intensive investment program for the years from 2014 to 2020, with a total budget of approx. PLN 15.3 billion. However, a significant difference as compared to the competitors is the large share of investments in the distribution business (approx. 63\% of the entire program). The small share of investments in the generation business is caused both by its relatively small share in the entire Energa Group, and by market uncertainty affecting this business area.

After PGE's unsuccessful attempt to take over Energa (late 2010/early 2011), the treasury chose to float the company on the stock exchange. Energa's shares, just like the shares of the other Polish power groups, are now quoted on the Warsaw stock exchange. Energa's relatively strong involvement in the regulated distribution market and limited exposure to the uncertain and — with the exception of PGE-hardly profitable generation business both translate into relatively high prices of Energa's shares. As of March 2015, Energa's market capitalization amounted to approx. PLN 9.5 billion.

The above overview shows quite clearly that the consolidation process led to the formation of a fairly large energy group, an average-sized group and two small groups. In addition, strong differentiation of assets between the groups - and thus their business profiles - constantly deepens the differences between the groups. 
Consequently, a question needs to be asked about whether the current structure of the market is its target structure, or perhaps - to successfully face the challenges ahead of the Polish power industry in the years to come - the market should keep developing, whether through further consolidation or through reorganization.

To assess the growth perspectives of the Polish power industry, it is necessary to analyze its current and future international context.

\section{European Electricity Market Policy for the Power Sector}

One of the fundamental objectives of the European power policy is to create an internal energy market. It needs to be noticed that the EU's use of the term "internal market" rather than the earlier term "common market" is not accidental. The terminological change introduced by the Treaty of Lisbon, as a result of that the notion of "common market" was replaced with "EU internal market", must not be seen merely as a vocabulary change. The notions of community and commonality emphasize the autonomy of involved parties. Common market is built of markets of autonomous parties (here: EU member states) which agreed to follow similar principles and to protect similar values. The EU internal market is a single market - it is not built of "building blocks" owned by different "owners", but rather it constitutes a single entity limited by the EU's external boundaries.

The Treaty on the Functioning of the European Union (TFEU) contains a provision on trans-European networks (title XVI). It stipulates that the Union contributes to the establishment and development of trans-European networks in the areas of transport, telecommunications, and energy infrastructures and aims at promoting the interconnection and interoperability of national networks as well as access to such networks (Article 170, ex Article 158 TEC). This means that the very fundamental assumptions on the functioning of the European Union contain the principle of supporting member states' actions aimed at creating an internal market, where electricity can be freely exchanged, without any barriers or discriminating factors.

In the energy sector, formation of a single internal market goes through a transition stage, at which regional markets are being created, i.e., trans-national markets that do not cover the entire territory of the EU. After such markets are fully integrated, they are expected to merge into a single market of the entire European Union (internal market). Poland belongs to the regional market of the Baltic Sea area and the regional market of Continental Central East, as shown in Figure 2 below.

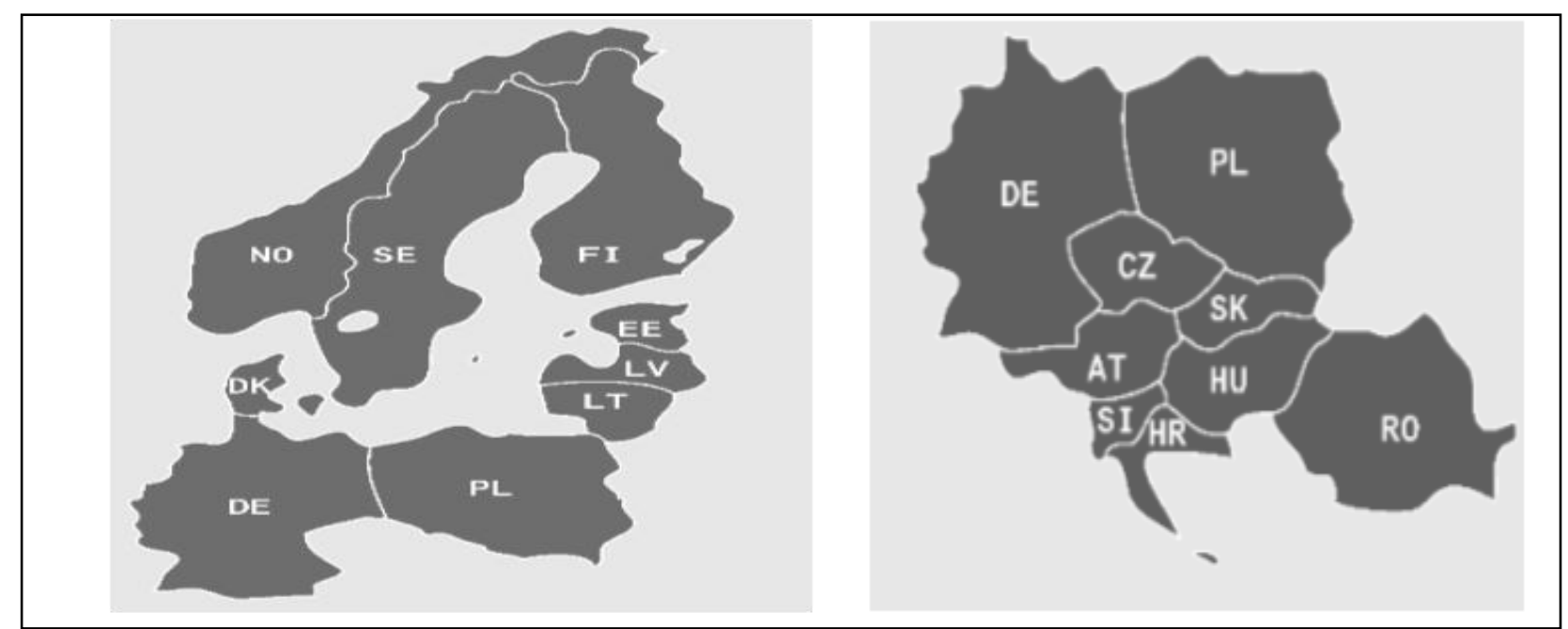

Figure 2. Regional energy markets including Poland-Baltic Sea and Continental Central East. Source: ENTSO-E (2014). 
The above assumptions were reflected in derivative acts of law of the European Union. The Communication of the European Commission of October 14, 2013 entitled Long Term Infrastructure Vision for Europe and Beyond states that,

The European energy system is in transition. Whilst the short term priority is to complete the internal energy market by developing the missing interconnectors, ending the isolation of a number of Member States and by removing internal bottlenecks, the energy infrastructure planned today must, at the same time, be compatible with longer term policy choices. (...) It is estimated that up to 2020 about $200 \mathrm{bn}$ euro investments are needed to upgrade and expand European energy networks to make them the central enabler of all our medium and long-term policy goals. This impressive figure, however, can entail important savings of up to 40-70bn euro on an annual basis by 2030 in terms of avoided generation costs and more competitive gas wholesale prices, translating into 7-12 euro savings in the monthly bills. This could greatly contribute to counterbalance the increase of energy prices and improve the Union industries' competitiveness. (European Commission, 2013a, pp. 2-3)

A long-term vision of the energy infrastructure policy was first presented in the communication entitled Energy Infrastructure Priorities for 2020 and Beyond-A Blueprint for an Integrated European Energy Network (European Commission, 2010), and subsequently included in the recently adopted regulation containing guidelines for trans-European energy infrastructure (European Commission, 2013c) (TEN-E guidelines).

The EC communication quoted above defines a long-term vision of pan-European energy infrastructure. The first batch of projects known as PCIs (projects of common interest) is an important step towards better integration of member states' networks, the purpose of which is to ensure that none of the member states remains isolated (European Commission, 2013a).

Figure 3 below shows an overview of currently adopted PCIs relating to electricity.

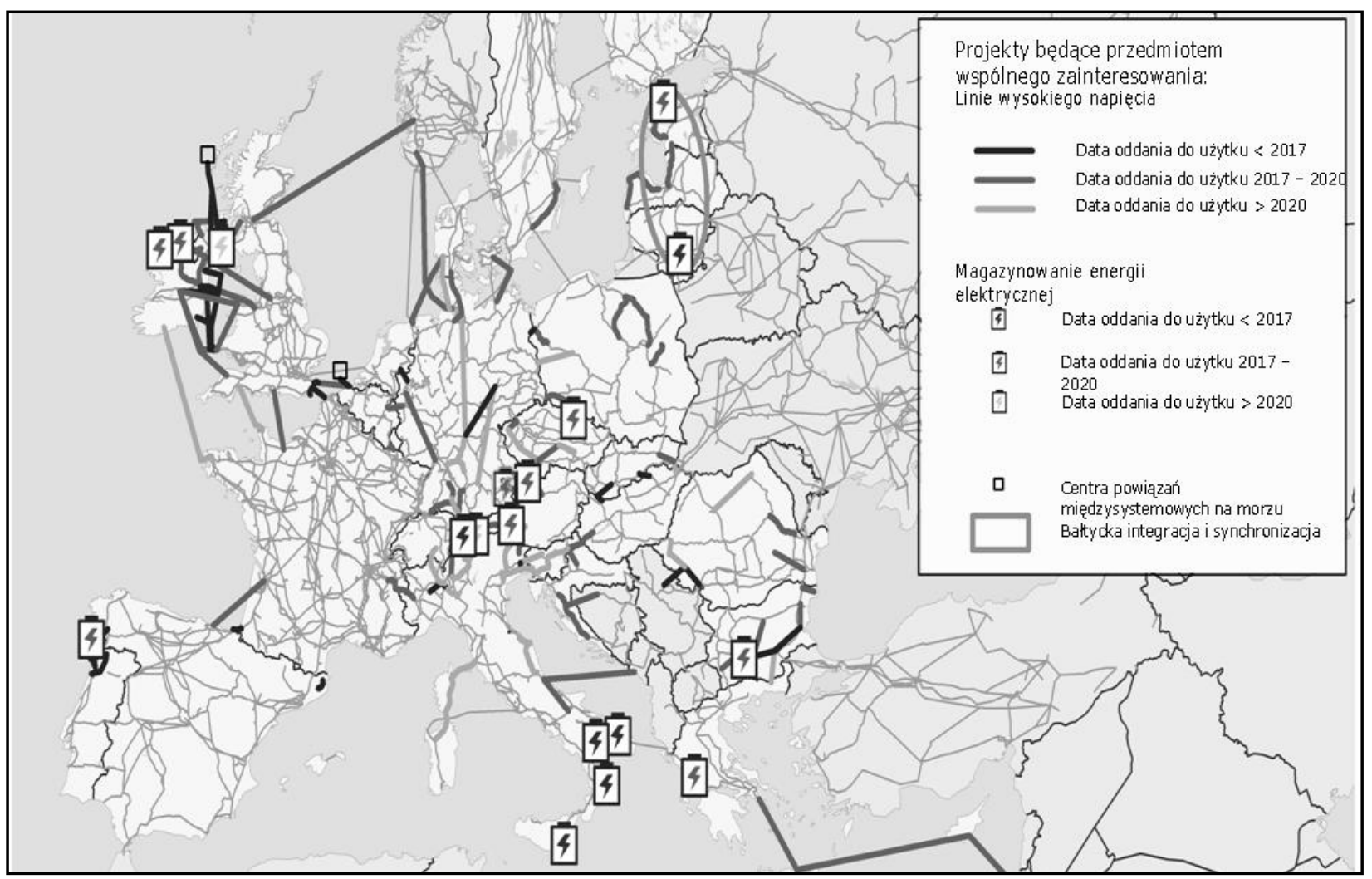

Figure 3. Map of projects of common interest (PCIs) in the energy sector. Source: European Commission (2013c). 


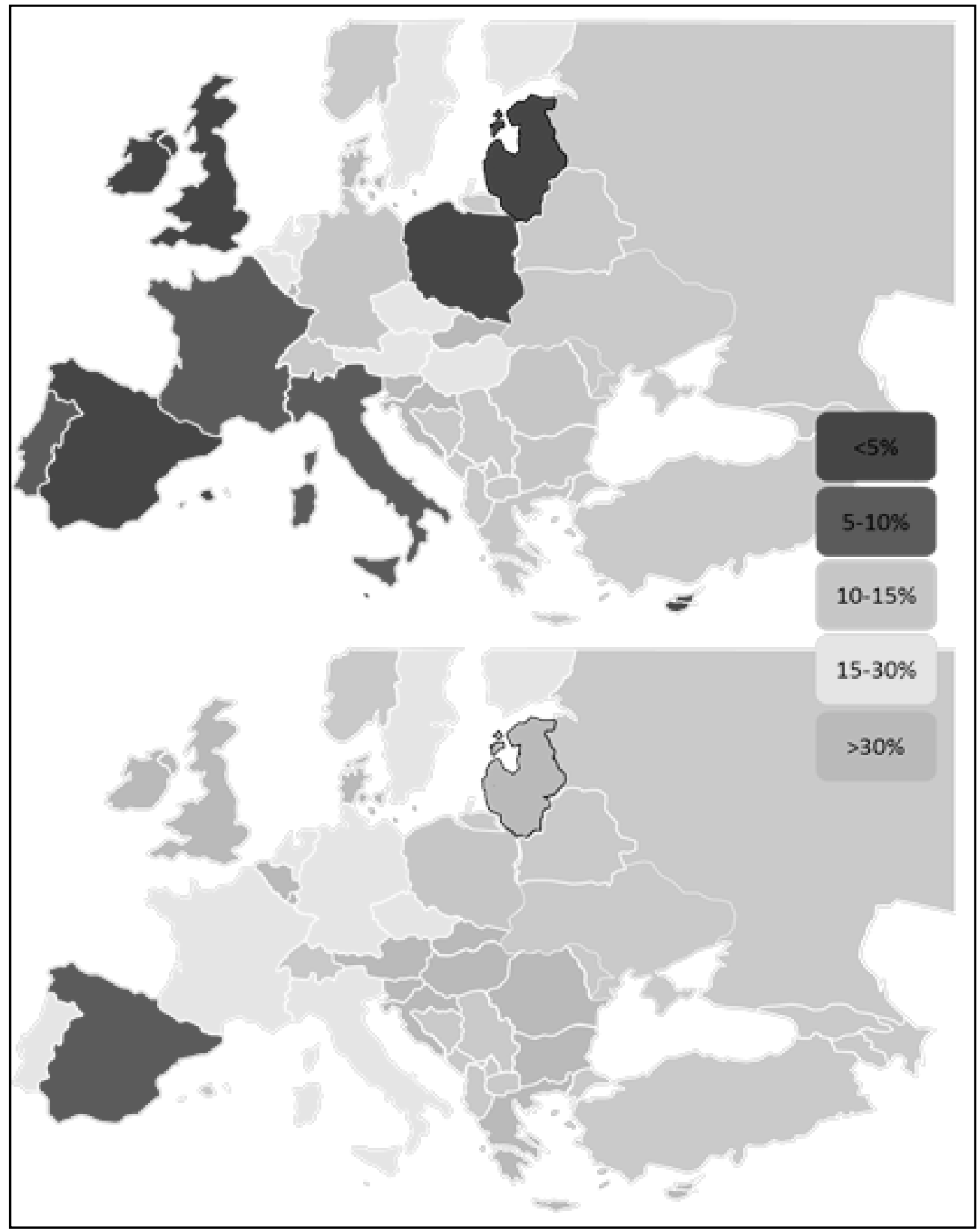

Figure 4. EU target of ensuring electricity interconnections at a level of at least $10 \%$ of installed generation capacity, before and after the PCIs. Source: European Commission (2013a).

As pointed out by the European Commission, most projects of common interest are in fact related to the electric power sector (mostly transmission lines). These projects are supposed to ensure better integration of the internal electricity market, increase networks' readiness to take in more energy coming from variable renewable energy sources, and help maintain system stability. As a result, the Union wants to achieve a target 
assuming interconnectivity corresponding to at least $10 \%$ of installed generation capacity. The target was recommended by the European Council in Barcelona in 2002 (European Commission, 2013a) (Figure 4).

Implementation of the program of extending interconnections as part of the internal energy market is also discussed in long-term policy papers relating to the development of the European energy sector, assuming possible development of renewable energy sources (European Commission, 2013b).

When projects of common interests (PCIs) are completed, the level of interconnectors linking Poland to other countries is supposed to grow from the current level (below $5 \%$ of the country's generation capacity) to between $10 \%$ and $15 \%$, i.e., a level currently observed, e.g., in Germany.

The importance of interconnectivity development (10\% target for 2020 and $15 \%$ target for 2030) in the EU's energy policy is further confirmed by the Framework for Climate and Energy EU 2030, containing conclusions from the European Council Summit held on 23 and 24 October 2014 (European Council, 2014).

Increasing the capacity of interconnectors for the purpose of building an internal energy market is seen as a way to solve many problems faced by the European energy market (greater competition, lower risk of market fraud, more rational investments, lower energy prices for end users, as well as greater security of energy supplies) (Domanico, 2007).

The European Commission stresses also the importance of competition in the internal market from the perspective of a reduction of wholesale prices. In a document entitled A Policy Framework for Climate and Energy in the Period From 2020 to 2030, the EC points out that,

High levels of competition in the internal energy market will be pivotal to deliver progress towards all objectives of the Union's energy policy in the 2030 timeframe. Simultaneously the Commission adds that competition on energy markets must also be enhanced through greater liberalization, completion of the internal energy market including the development of energy transport infrastructure including cross-border interconnectors that may be more efficient in ensuring security of supply than support for domestic generation capacity. (European Commission, 2014, p. 12)

Another important argument in favor of creating an internal energy market is the efficiency of using renewable energy sources, which - unlike conventional sources - are strongly correlated with geographical and environmental conditions prevailing in a given area. For instance, it has been noted that in 2011 Germany had $35 \%$ of the global photovoltaic generation capacity, while Italy had only $18.3 \%$ and Spain as little as $6.5 \%$, even though the same generation capacity in Spain—due to much more solar radiation—could generate twice as much electricity as in Germany. From the perspective of the internal market, such allocation of photovoltaic sources is obviously far from optimal (Böckers et al., 2013).

In the above context, it is hardly surprising that one of the key indicators used to monitor the progress of the above-described energy policy will be the assessment of the construction of smart grids and cross-border interconnectors. It is particularly urgent in the case of those states (including Poland) that are the most behind the agreed target for member states, assuming a level of interconnectivity corresponding to at least $10 \%$ of their installed generation capacity (European Commission, 2014; European Council, 2014).

It is being pointed out that it is hard to judge what level of interconnectivity will ensure a truly integrated energy market. Extreme situations are quite obvious - in the absence of any interconnectors, markets will remain autonomous. If the capacity of interconnectors corresponds to the maximum demand, markets are undoubtedly fully integrated (generation in market A can meet the entire demand in market B). It is only natural that all scenarios between the two extremes are less obvious and require one to analyze whether price pressure from market A translates into price levels in market B (Böckers et al., 2013). 
It should be noted here that in the late 2010, PGE took an unsuccessful attempt at taking-over Energa. The transaction was disallowed by the Polish antitrust authority (Office of Competition and Consumer Protection [UOKiK], 2011a).

The antitrust authority concluded that as of the beginning of 2011, the Polish electricity market was hardly open to other markets and in fact did not participate in the regional (trans-national) market. Simultaneously, the authority pointed out that in its view, the effect on market concentration should be assessed by taking into account first of all current market conditions (UOKiK, 2011a). From the early 2011, perspective the authority indicated that,

Taking into account a perspective of several years, there will be no significant increase in the commercial exchange of electricity with neighboring countries. In addition, it needs to be noted that due to the fact that the first new interconnectors will become operational not earlier than in 5 years, the authority notices a major risk of delays in or postponement of those projects. (...) In the context of possible market development resulting in the possibility of extending the definition of the market (also in the geographical aspect), the authority believes that one can take into account the conditions that will prevail in the future. However, there should exist certainty that the said changes will in fact take place, and secondly - the period in which such changes are to occur should not be longer than several years. Namely, the longer the period, the more difficult it will be to foresee (and thus to evaluate) the market situation. (UOKiK, 2011a, p. 52)

After four years and given the development directions of the European energy policy, it seems that the authority's approach was somewhat short-sighted.

In nearly all developed European markets, significant concentration of the energy sector has been observed for over a decade. Some suggested that one of its results could be oligopolization of the European internal market by pan-European players (Domanico, 2007). Under such circumstances, the advancing consolidation is hardly surprising. Power companies have focused on increasing their critical mass in order to survive in the market and to minimize the risk of being taken-over (Verde, 2008). Furthermore, already in 2007, it was noted that while geographical limitation of transmission and distribution services to the boundaries of a given network is quite obvious (as a rule, such boundaries correspond to national borders), in the face of advancing consolidation of the industry in Europe, it is recommended to extend the geographical boundaries of electricity generation markets (Verde, 2008).

The unsuccessful attempt at taking over Energa by PGE has been already analyzed (Kamiński, 2014), but the main focus of that analysis was on econometric assessment of the effect of further growth in PGE's share in the domestic generation market on potential electricity prices. Without arguing with the assumptions of the model used, it is worth pointing out that an assessment of concentration should be all-inclusive, also in the light of the present and future market environment. Even if greater concentration in a given market may lead to an even temporary growth in energy prices paid by end users and to a general reduction of the society's wealth, then its only natural that a broader approach to the market (e.g., in the face of greater interconnectivity with other markets) may minimize those adverse effects (Borenstein, Bushnell, \& Knittel, 1999; Domanico, 2007). It is also worth pointing out that the essence of possible consolidation would not be an increase in the generation market share (a "purely" horizontal consolidation - from the perspective of PGE, there have existed multiple possible take-overs that are much cheaper than Energa and that allow increase in the generation capacity), but a better balancing of the group (vertical consolidation to some extent-greater share of distribution and trading after consolidation). However, one may agree with a conclusion that the very increase of PGE's advantage over the other players in the Polish market (until an adequate level of its integration with the EU's internal 
market/regional markets is reached) would not be a favorable solution from the wealth perspective. It needs to be noted that the German example shows that consolidation of smaller players from a given market (around Vattenfall) may weaken the competitive advantage of market leaders (E.ON and RWE) and improve the situation of end users (Keller, 2010). Thus, it seems that a comprehensive approach to the Polish power industry is necessary in order to create a framework for the country's new energy order, reflecting the challenges faced by the sector.

The situation described above may pose a serious threat to the competitive position of Polish power groups. First, integration of energy markets among member states is one of the top priorities of the European Commission. It can be claimed that actual integration of the Polish energy market at least at the level of regional markets (Baltic Sea area and Continental Central East) - and thus price convergence - is merely a question of time. In other words, in the current political and market situation, the question is not whether Polish companies will feel price pressure from the neighboring countries of the EU, but when such pressure will appear.

Second, it follows from strategic documents of the EU that market integration, rather than supporting member states' own generation capacity makes the key tool for ensuring security of energy supplies. It needs to be remembered that an intensive development of renewable energy sources in all member states makes Poland — dominated by high-emission power plants based on hard and brown coal—an attractive sales market. This means that it is highly likely that the future direction of development of the EU's energy policy will reduce the possibility of supporting Polish energy groups, exposing them to strong competition from other European players.

However, it needs to be remembered that investment processes in the power industry are highly time and capital intensive (Domanico, 2007). Thus, if Polish companies want-relying on relatively high wholesale energy prices - to reinforce their competitive position in the regional market and in the future internal market of the European Union, it may be necessary to reinforce their position now. It must be remembered that the question of creating strong groups before full liberalization of energy markets was one of the main reasons behind both domestic and trans-border concentrations in the power industry (Verde, 2008). It is being pointed out that the strategy of European energy groups in the context of the planned formation of the internal (previously: common) market was also based on consolidation. Once markets become open, merged entities should enjoy two types of consolidation benefits: first, greater presence on the EU market; and second, a form of protection against being taken-over (Verde, 2008).

\section{Polish Power Companies and the European Electricity Market}

The European market is dominated by several leading energy companies. Undoubtedly, there are no Polish players among them. A comparison of Polish energy groups' EBITDAs with those of their European competitors shows a major gap separating Polish companies from their western competitors (Figure 5).

Simultaneously, the Polish energy market, as compared to Europe, remains relatively fragmented.

The level of concentration is usually measured with Herfindahl-Hirschman Index (HHI), showing the sum of the squares of the market shares of all companies within the industry. The level of concentration of a given industry denotes its degree of monopolization and creates structural conditions for competition. The higher the value of the index is, the less the competition is in the industry (UOKiK, 2011b). 


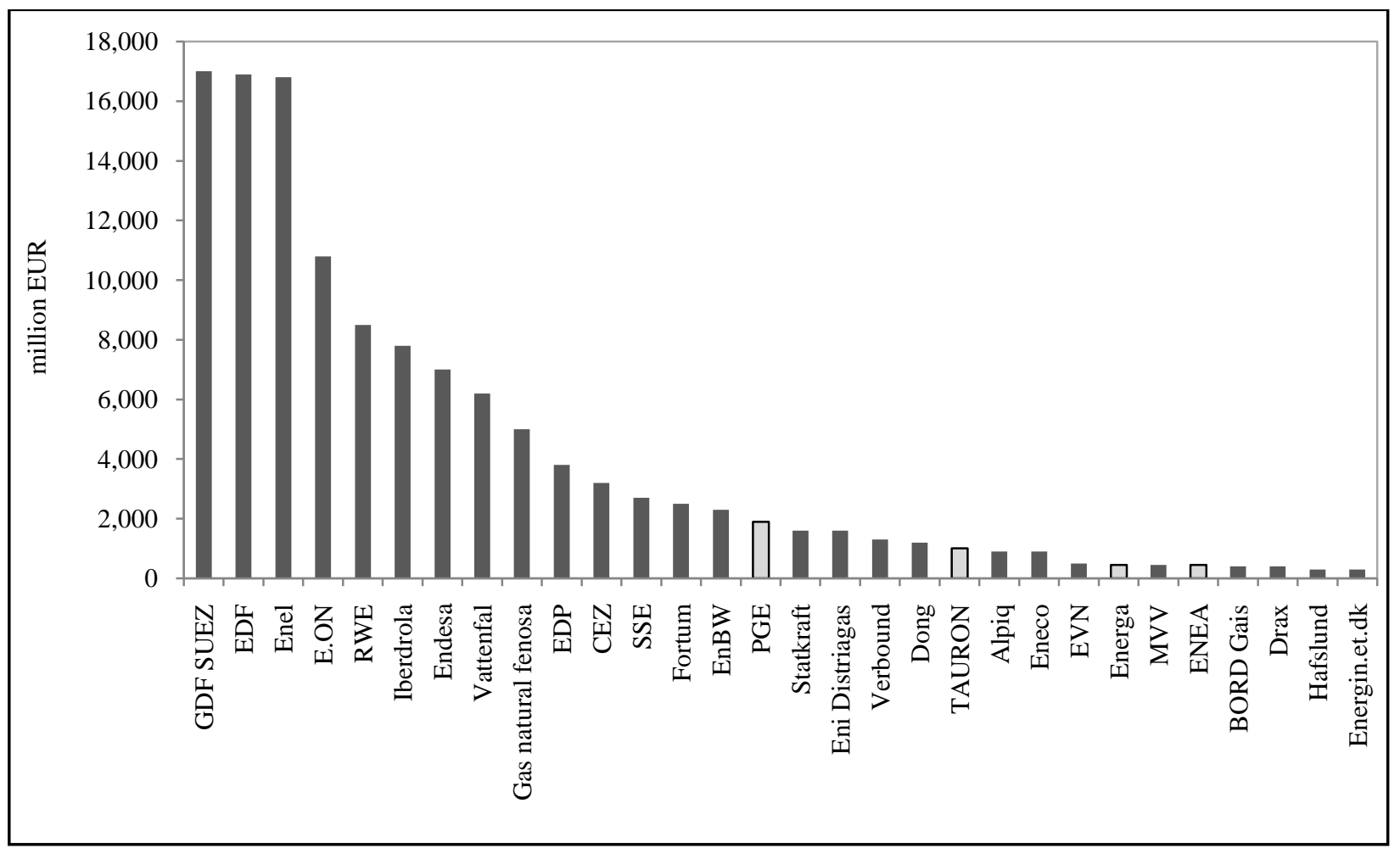

Figure 5. EBITDA (EUR million) of European power companies in 2012. Source: CapGemini (2013), Polska Grupa

Energetyczna S.A. (2012), TAURON Polska Energia (2012), ENEA S.A. (2012), and Energa S.A. (2012).

It is assumed that with $\mathrm{HHI}$ below 1,000, an industry is not concentrated. HHI from 1,000 to 1,800 denotes a moderately concentrated industry and HHI above 1,800 means that the industry in question is highly concentrated. If HHI stays at a level above 5,000, it means that concentration is very high. Such a situation may occur, e.g., when one company holds at least $70 \%$ of the retail electricity market or when three players hold shares exceeding $30 \%$. The maximum value $(10,000)$ means a full monopoly (one company holding $100 \%$ of the market).

Individual power generation markets in Europe are highly concentrated. This fact follows from energy infrastructure's strategic importance for economic security of the state. As a result, in many countries, the ownership structure of power plants is concentrated around state-controlled power groups (EdF in France, CEZ in the Czech Republic). A relatively strong concentration of the generation sector ( $\mathrm{HHI}>4,000)$ is typical for Central and Eastern Europe, where the formation of a competitive energy market began a relatively short time ago (Agencja Rynku Energii S.A., 2013).

It needs to be remarked that introduction of renewables into the system reduces HHI calculated on the basis of installed power, which follows from the specific nature of those energy sources. Taking into account the market share of energy fed into the grid (and not installed power), HHI value for Poland in 2012 and 2013 was 2,096 and 1,992, respectively (Energy Regulatory Office, 2014).

The below Table 2 shows that as compared to other EU countries (even if HHI calculated on the basis of energy fed into the grid is taken into account), Poland has a relatively low concentration. The fact that the concentration level in Poland exceeds levels denoting high market concentration results from the nature of this market. Only in some highly developed markets (UK, Italy, and Spain), HHI for generation capacity structure 
(which, as a rule, decreases in line with the growing share of renewables) was lower than that in Poland. In some countries (France, Czech Republic, Estonia, Slovakia, and Belgium), HHI values indicate very high concentration (above 5,000).

Table 2

HHI Values for Generation Capacity Structure in Selected EU Countries in 2011

\begin{tabular}{|c|c|}
\hline Country & $\mathrm{HHI}$ \\
\hline Belgium & 5,380 \\
\hline Bulgaria & no data available \\
\hline Czech Republic & $>5,000$ \\
\hline Cyprus & no data available \\
\hline Denmark & no data available \\
\hline Germany & 2,021 \\
\hline Estonia & $>7,500$ \\
\hline Ireland & no data available \\
\hline Greece & no data available \\
\hline Spain & 1,361 \\
\hline France & 8,880 \\
\hline Finland & no data available \\
\hline Lithuania & 4,092 \\
\hline Luxembourg & no data available \\
\hline Malta & no data available \\
\hline Hungary & no data available \\
\hline Holland & 1,811 \\
\hline Austria & no data available \\
\hline Poland & 1,835 \\
\hline Portugal & no data available \\
\hline Romania & 1,947 \\
\hline Slovenia & 4,892 \\
\hline Slovakia & 5,280 \\
\hline Sweden & 2,650 \\
\hline UK & 947 \\
\hline Italy & 1,087 \\
\hline
\end{tabular}

Source: Agencja Rynku Energii S.A. (2013).

Another metric showing the degree of concentration is the number of entities holding at least $5 \%$ of the market. In Poland in 2012 and 2013, there were five companies holding at least 5\% of installed capacity and six companies holding a share of 5\% or more in energy fed into the grid. These figures make Poland one of the EU leaders, as illustrated by the Figures 6 and 7 below.

Only in the UK and Romania, the market is more fragmented than in Poland (when measured with this particular indicator).

In addition to issues related to the number of players in the energy generation sector, another parameter of importance for the industry's competitiveness is the market share of the largest market player. It can be seen for instance in Belgium, where the number of generators holding at least $5 \%$ of the market was three, and the share of the largest producer was nearly $80 \%$. Under such circumstances, there is hardly any competition in the 
generation sector. It needs to be noted that, as seen in Poland, a high market share may be coupled with the fact that the market leader owns the most cost-efficient generation sources (in Poland: brown coal/PGE). A similar situation is observed also in France (EdF) and in the Czech Republic (CEZ), where market leaders own nuclear power plants.

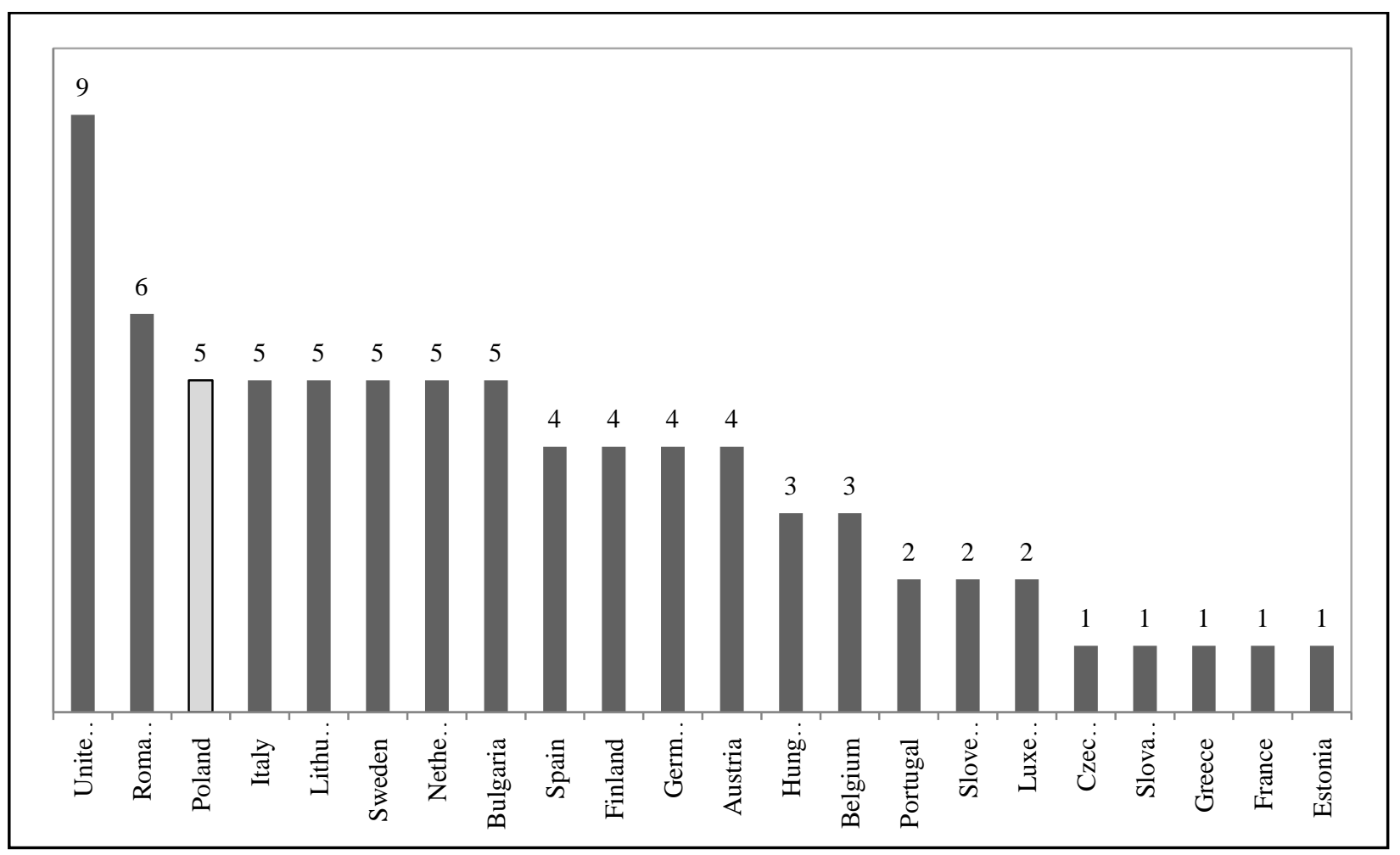

Figure 6. Number of companies holding more than $5 \%$ of the electricity generation market in selected EU countries in 2011. Source: Agencja Rynku Energii S.A. (2013).

As shown, with the market leader (PGE) holding 38\% of the market, Poland stayed below the EU average.

Nonetheless, it needs to be noted that a high degree of concentration of the electricity generation market does not automatically mean higher prices, as shown by an analysis of electricity prices on European power exchanges.

As illustrated by the below Figure 8, wholesale energy prices in the highly concentrated French market (EPEX France) are comparable with prices in Germany (EPEX Germany) and far lower than in Italy (IPEX). Such a situation results first of all from access to low-cost generation capacity, the construction of which requires significant financial expenditures. Furthermore, French nuclear generation capacity concentrated in EdF can offer better prices than sources based on fossil fuels (e.g., in Germany), irrespectively of the fact that the German market is more competitive (Bower, Bunn, \& Wattendrup, 2001). Paradoxically, it is possible that higher concentration in the generation sector leads to lower prices (also for end users).

Obviously, the consequences of M\&As in the power industry have already been analyzed (Kwoka \& Pollitt, 2010; Keller, 2010; Verde, 2008). This paper does not aim at judging those consequences, whether in an abstract manner or specifically for the Polish market or the internal market of the EU. First, it needs to be noted that voices claiming positive effects of consolidation on power market efficiency can be heard (research concentrates first of all on the generation business) (Keller, 2010), despite some views to the contrary (Kwoka 
\& Pollitt, 2010). Second, it is being emphasized that an adequate regulatory policy may allocate most benefits from consolidation towards energy consumers (Ray \& Thompson, 1990), which results from the specific nature of regulated markets. A fine example could be the distribution sector, where the so-called regulated revenues (based on rates subject to an approval by the President of the Energy Regulatory Office) involve transfer of at least part of savings to customers and prevent excessive price growth. Third, possible short-term price growth should be balanced in the mid-term by external pressure, as the Polish market becomes integrated with neighboring EU markets (or more broadly - with the EU internal market) (Borenstein et al., 1999). Fourth, it needs to be noted that while it is being pointed out that a natural consequence of mergers could be a tendency to reduce generation capacity by closing down the least cost-efficient sources (thus reducing the available power reserve) (Bower et al., 2001), in the Polish case, such risk is minimized by the shareholding structure of the main market players. State-controlled entities by nature will take their investment and divestment decisions bearing in mind the interests of the main shareholder (the state). Those interests include inter alia security of energy supplies requiring adequate generation capacity.

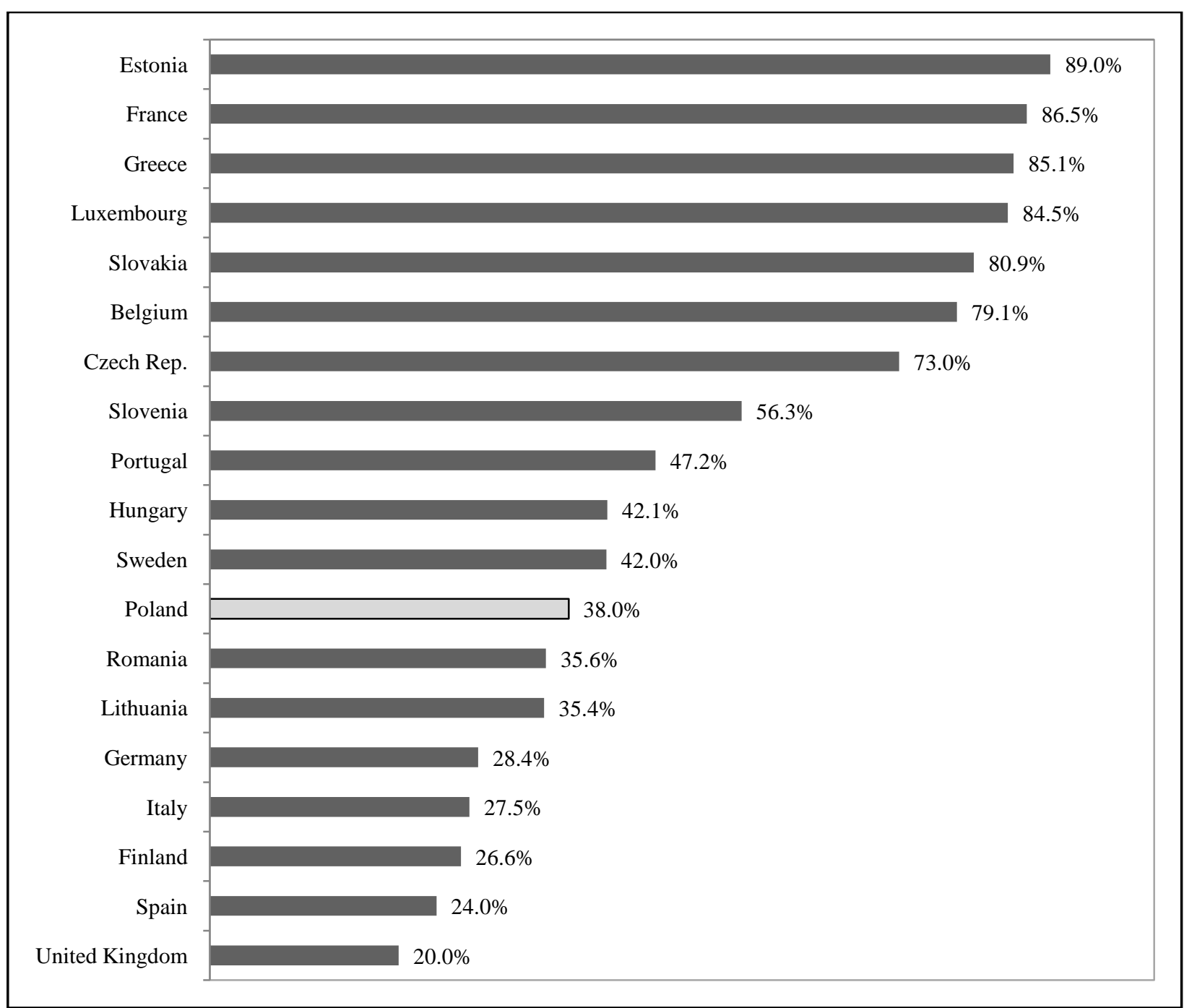

Figure 7. Market share of the market leader in the power generation structure in 2011. PGE figure is from 2012. Source: Agencja Rynku Energii S.A. (2013). 


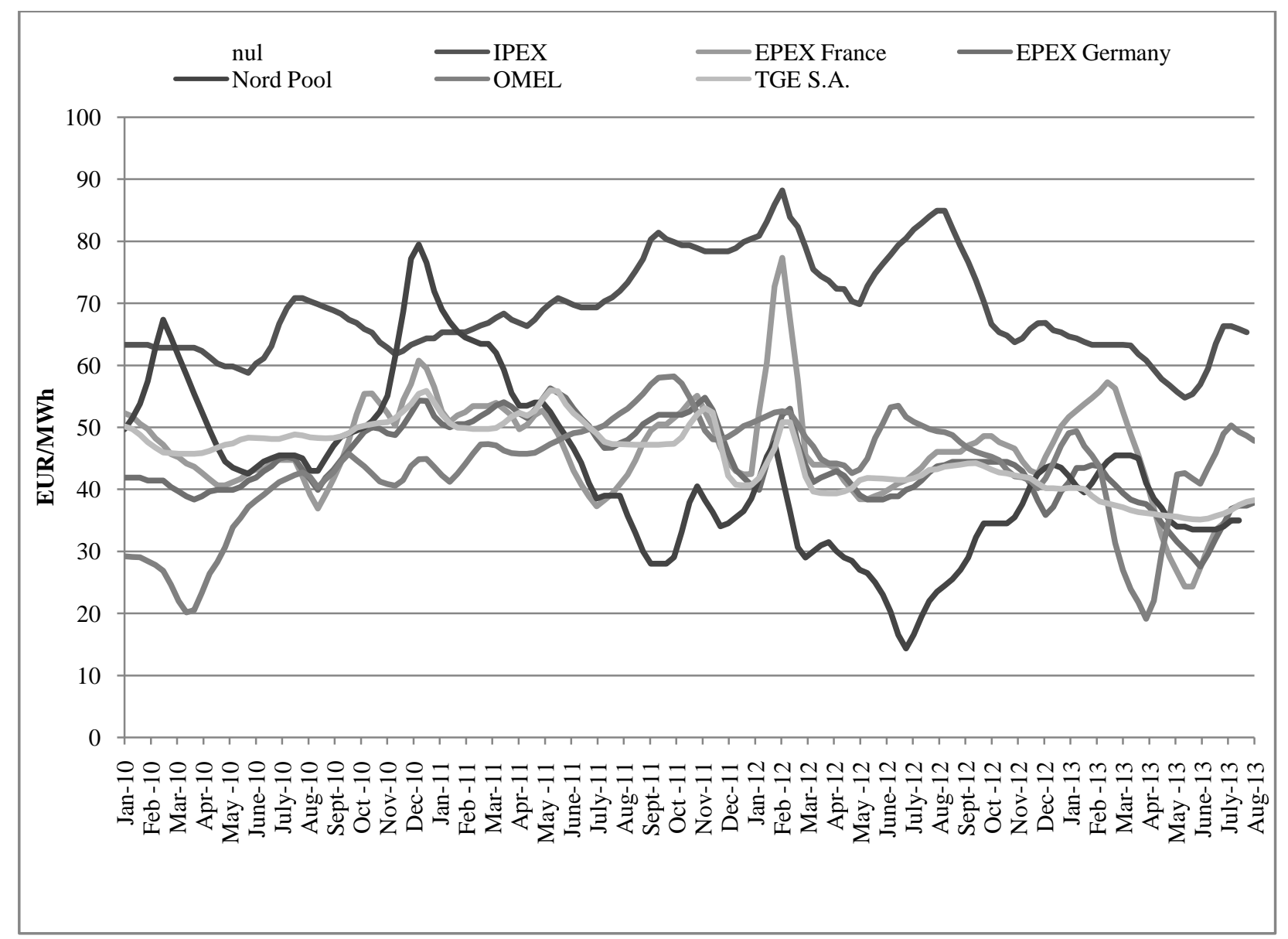

Figure 8. Average monthly energy prices on European power exchanges in spot transactions (EUR/MWh). Source: Agencja Rynku Energii S.A. (2013).

The above figures are presented, as if each domestic market was autonomous. However, it is important to bear in mind the directions of the EU energy policy and its commitment to create a common market. Based on 2012 figures and assuming that market shares of each player does not change until the formation of a true internal energy market in the EU, the largest company would hold approximately $20 \%$ of that market and there would be six companies holding more than 5\%. HHI value for electricity generation in the EU would be significantly higher than 1,000 , but it could be expected that in line with the growth of renewable energy sources and distributed energy generation, the said share will continue to decrease. Obviously, shares held by Polish companies in the EU electricity generation market would be marginal, as illustrated by Figure 9 below.

As compared to the other national markets of the EU, the Polish market is relatively little concentrated, which is confirmed by a relatively low HHI value, a significant number of large energy producers (depending on the approach: installed power or energy fed into the grid-five or six companies, respectively) and a moderate market share of the largest energy producer (PGE, approx. 40\%).

It should also be noted that a low level of concentration does not need to translate into low energy prices, which is illustrated by the concentrated (at least at the national level) markets of France, Czech Republic, or Slovakia. However, the reasons for such a situation may vary. 
Simultaneously, the market position of Polish generators remains insignificant given the scale of the European internal market. With EBITDA at a level of approx. EUR 2 billion, the largest Polish power company (PGE) occupies a place in the lower sections of the top 20 European companies. The results of the other groups (TAURON, ENEA, and Energa) are negligible in the context of the European market.

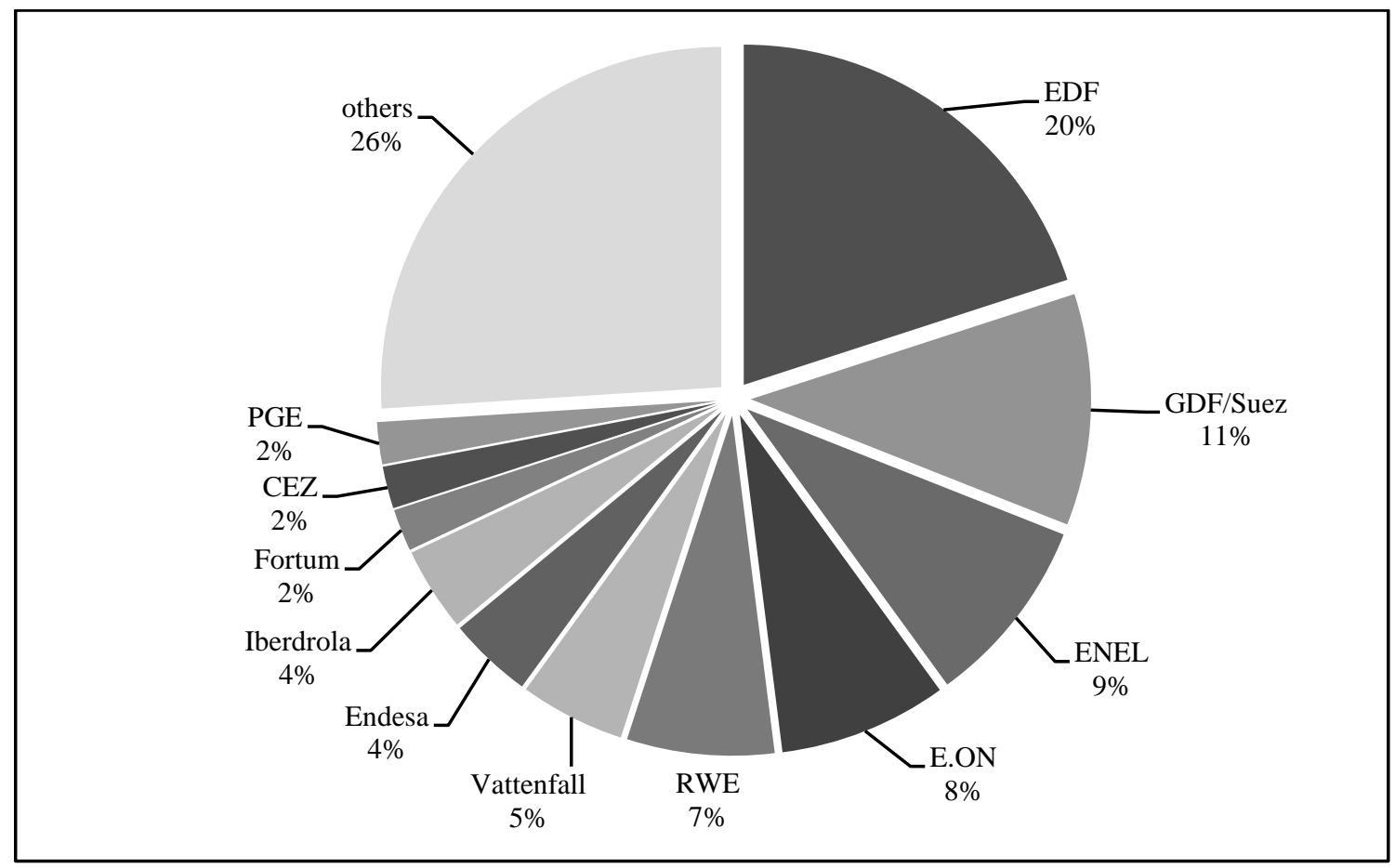

Figure 9. Share of the largest producers in electricity generation in the EU in 2012. Source: Agencja Rynku Energii S.A. (2013) and Eurostat (2012).

\section{Conclusions}

The consolidation of the Polish power industry in the middle of the previous decade was a move in the right direction. It led to the formation of four vertically integrated groups controlled by the Treasury. All of them are quoted on the Warsaw stock exchange, which enhances information transparency and has a positive effect on the competition among those groups. Moreover, consolidation made it possible to implement some investments necessary to renew generation capacity and to increase distribution grid stability in a rational manner. By nature, vertically integrated companies enjoy greater financial strength (and are thus capable of financing large investment projects) than individual power and CHP plants (as regards generation) or energy companies (as regards distribution). The above assumption is particularly well visible in the generation business, where the variability of results (caused by variable wholesale electricity prices on the one hand and by variable prices of fuel, $\mathrm{CO}_{2}$ emission entitlements and certificates of origin on the other) generates significant investment risks. However, it needs to be remembered that due to the lengthy investment process, most projects are planned and implemented based on assumptions that are completely different from the future market reality. Consequently, investment risks can only be faced by entities of adequate size and diversification. Obviously, the above arguments are not unique to the Polish energy market. The issue of establishing adequately large entities before full liberalization of energy markets was pointed out as one of the key factors behind national and trans-border concentrations in the power industry (Verde, 2008). 
Consolidation itself was beneficial for the market participants. Nonetheless, it needs to be asked whether it has given the market a correct shape. Attention must be drawn here to systemic imbalance among each of the vertically integrated groups. While the areas of distribution and sales are in a state of relative equilibrium (particularly if the specific nature of these business areas is taken into account), the differences among each group in the generation area are huge.

Another poignant issue is the fact that the Treasury chose to differentiate business profiles of the power groups. While TAURON's strong exposure to the distribution and trading business results from the company's business decisions (acquisition of distribution and trading assets from Vattenfall), formation of Energa with very little exposure to the generation market resulted from the government's decision (approx. 80\% of EBITDA from the distribution business, as compared to $30 \%$ to $60 \%$ in the other power groups). Furthermore, it needs to be remembered that in the case of vertically integrated groups greater security of investments in new generation capacity is owed to stable cash flows from the distribution business. Simultaneously, replacement of generation capacity is of key importance for energy security of the state.

So far, the Polish energy market has preserved its national character, which results from the low capacity of interconnectors. As a result, in 2014 wholesale electricity prices in Poland were by approximately $25 \%$ higher than those in the neighboring markets of Germany, Czech Republic, Slovakia, Denmark, and Sweden. Nonetheless, looking to the future, one should note that some markets neighboring with Poland have effectively created a regional or trans-national market (Germany, Czech Republic, Slovakia, Denmark, and Sweden). Uniform energy prices in those markets are the ultimate proof for that assumption.

Together with the development of interconnections with Poland, strong pressure on Polish prices will appear and Polish energy groups will have to compete against other European electricity producers. Currently, the European level of wholesale energy prices is considerably lower than the Polish prices, which is a major challenge for domestic companies in the case of greater opening of the Polish market to energy imports.

From the perspective of the Polish power groups, it is necessary to answer the question about whether it is realistic for Poland to actually join other regional energy markets (first of all, markets including Germany, Czech Republic, Slovakia, Denmark, and Sweden). An analysis of the development direction of the European energy policy suggests that the answer to the above question is yes.

Integration of energy markets among member states is one of the top priorities of the European Commission. It can be claimed that actual integration of the Polish energy market at least at the level of regional markets (Baltic Sea area and Continental Central East) - and thus price convergence-is merely a question of time. In other words, in the current political and market situation, the question is not whether Polish companies will feel price pressure from the neighboring countries of the EU, but when such pressure will appear. Furthermore, it follows from strategic documents of the EU that market integration, rather than supporting member states' own generation capacity makes the key tool for ensuring security of energy supplies. Such an approach may be particularly dangerous for Polish power companies. This means that it is highly likely that the future direction of development of the EU's energy policy will reduce the possibility of supporting Polish energy groups, exposing them to strong competition from other European players.

It needs to be remembered that investment processes in the power industry are highly time and capital intensive. Thus, if Polish companies want-relying on relatively high wholesale energy prices - to reinforce their competitive position in the regional market and in the future internal market of the European Union, it may be necessary to reinforce their position now. As compared to the other national markets of the EU, the 
Polish market is relatively little concentrated, which is confirmed by a relatively low HHI value, a significant number of large energy producers (depending on the approach: installed power or energy fed into the grid-five or six companies, respectively) and a moderate market share of the largest energy producer (PGE, approx. $40 \%)$.

It should also be noted that a low level of concentration does not need to translate into low energy prices, which is illustrated by the concentrated (at least at the national level) markets of France, Czech Republic, or Slovakia. However, the reasons for such a situation may vary. Simultaneously, the market position of Polish generators remains insignificant given the scale of the European internal market. With EBITDA at a level of approx. EUR 2 billion, the largest Polish power company (PGE) occupies a place in the lower sections of the top 20 European companies. The results of the other groups (TAURON, ENEA, and Energa) are negligible in the context of the European market.

In the situation described above, the next step should be further consolidation of the Polish power industry. However, it should not be achieved by deepening the differences among the country's major energy groups (i.e., by further reinforcing of PGE's position vis-à-vis its competitors). It needs to be remembered that such unilateral concentration was already disallowed by the Polish antitrust authority in early 2011. In the face of advancing integration of the European market (development of regional markets and eventually formation of the EU's internal market), adaptation of the Polish generation assets to competitive requirements will call for consolidation involving not only the market leader, but the other players as well.

Ideally, such consolidation should result in the creation of approximately three robust and relatively balanced entities, capable of implementing investment programs. They should be balanced in terms of both the types of generation assets (brown coal, hard coal, RES, and possibly gas and nuclear energy in the future) and the share in the regulated and stable revenues from the distribution business that will cushion the impact of uncertain generation and trading business.

\section{References}

Agencja Rynku Energii S.A. (2013). Functioning of enterprises in the Polish and European power markets. Warsaw: ARE Publishing House.

Agencja Rynku Energii S.A. (2014). Technical and economic situation of the power market - 4 Quarters of 2013. Warsaw: ARE Publishing House.

Böckers, V., Haucap, J., \& Heimeshoff, U. (2013). Benefits of an integrated European electricity market: The role of competition. Retrieved from http://www.europarl.europa.eu/RegData/etudes/etudes/join/2013/504466/IPOL-JOIN_ET\%282013\%29504466\%28ANN04 $\% 29 \_$EN.pdf

Borenstein, S., Bushnell, J., \& Knittel, C. R. (1999). Market power in electricity markets: Beyond concentration measures. The Energy Journal, 20(4), 65-88.

Bower, J., Bunn, D. W., \& Wattendrup, C. (2001). A model-based analysis of strategic consolidation in the German electricity industry. Energy Policy, 29, 987-1005.

CapGemini. (2013). European energy markets observatory (15th ed.). Retrieved from https://www.capgemini.com/resources/european-energy-markets-observatory-2013-full-study

Domanico, F. (2007). Concentration in the European electricity industry: The internal market as solution? Energy Policy, 35, 5064-5076.

ENEA S.A. (2012). Report of the board of directors of ENEA S.A. Retrieved from http://ir.enea. pl/file/attachment/658582/88/sprawozdanie_zarzadu_z_dzialalnosci_grupy_kapitalowej_enea_w_i_polroczu_2012_r.pdf

Energa S.A. (2012). Report of the board of directors of Energa S.A. Retrieved from http://www.ir.energa.pl/file/static/12734/c4/skonsolidowane-sf-2012-z-opinia-i-sprawozdaniem-z-dzialalnosci.pdf 
Energy Regulatory Office. (2012). Report from the activities of the President of the Energy Regulatory Office 2011. Retrieved from http://www.ure.gov.pl/download/2/244/NationalReport2011.pdf

Energy Regulatory Office. (2014). Report from the activities of the President of the Energy Regulatory Office 2013. Retrieved from http://www.ure.gov.pl/download/2/443/ActivityReport2014.pdf

European Commission. (2010). Energy infrastructure priorities for 2020 and beyond-A blueprint for an integrated European energy network. Retrieved from http://eur-lex.europa.eu/legal-content/EN/TXT/?uri=COM:2010:0677:FIN

European Commission. (2013a). Long term infrastructure vision for Europe and beyond. Retrieved from http://eur-lex.europa.eu/resource.html?uri=cellar:a2574790-34e9-11e3-806a-01aa75ed71a1.0007.01/DOC_1\&format=PDF

European Commission. (2013b). EU energy, transport and GHG emissions, trends to 2050, reference scenario 2013, Brussels 2013. Retrieved from http://ec.europa.eu/transport/media/publications/doc/trends-to-2050-update-2013.pdf

European Commission. (2013c). Regulation (EU) No. 347/2013, OJ L 140 of 25.04.2013. Retrieved from http://eur-lex.europa.eu/legal-content/EN/ALL/?uri=CELEX:32013R0347

European Commission. (2014). A policy framework for climate and energy in the period from 2020 to 2030 . Retrieved from http://eur-lex.europa.eu/legal-content/EN/TXT/PDF/?uri=CELEX:52014DC0015\&from=EN

European Council. (2014). Framework for climate and energy EU 2030. Retrieved from http://www.consilium.europa.eu/uedocs/cms_data/docs/pressdata/en/ec/145397.pdf

European Network of Transmission System Operators for Electricity [ENTSO-E]. (2014). Regional investment plan 2014. Continental Central East. Retrieved from https://www.entsoe.eu/major-projects/ten-year-network-development-plan/tyndp-2014/Pages/default.aspx

Eurostat. (2012). Gross electricity generation by fuel. Retrieved from http://ec.europa.eu/eurostat/statistics-explained/index.php/File:Gross_electricity_generation_by_fuel,_GWh,_EU-28,_1990-2 012.png

Kamiński, J. (2014). A blocked takeover in the Polish power sector: A model-based analysis. Energy Policy, 66, 42-52.

Keller, A. (2010). Competition effects of mergers: An event study of the German electricity market. Energy Policy, 38, 5264-5271.

Kwoka, J., \& Pollitt, M. (2010). Do mergers improve efficiency? Evidence from restructuring the US electric power sector. International Journal of Industrial Organization, 28, 645-656.

Ministry of Economy of the Republic of Poland. (2006). Program for the electric energy sector. Retrieved from http://www.msp.gov.pl/download.php?s=1\&id=105

Ministry of Treasury of the Republic of Poland. (2003). Programme for the realisation of the ownership policy of the minister of the treasury concerning the sector. Retrieved from http://bip.msp.gov.pl/download/1/3008/Programrealizacjipolitykiwlascicielskiejwodniesieniudosektoraelektroenergetyczne.p df

Office of Competition and Consumer Protection [UOKiK]. (2011a). Decision of the president of UOKiK of January $13,2011$. Retrieved from https://uokik.gov.pl/download.php?plik=9494

Office of Competition and Consumer Protection [UOKiK]. (2011b). Consumer's position on the electricity market. Retrieved from https://uokik.gov.pl/download.php?plik=10178

Polska Grupa Energetyczna S.A. (2014). Report of the board of directors of PGE Polska Grupa Energetyczna S.A. Retrieved from http://www.gkpge.pl/media/pdf/SZ_PGE_2014.pdf

Ray, D. J., \& Thompson, H. E. (1990). Fifty in five: The prospects for merger in the electric utility industry. Journal of Regulatory Economics, 2(1), 111-128.

Supreme Chamber of Control. (2009). Information on the results of an inspection of the power sector restructuring reform and energy grids safety. Retrieved from https://www.nik.gov.pl/plik/id,70,vp,70.pdf

TAURON Polska Energia (2012). Report of the board of directors of TAURON Polska Energia. Retrieved from http://www.tauron.pl/sitecollectiondocuments/tpe/06.\%20sprawozdanie\%20zarz\%C4\%85du\%20z\%20dzia\%C5\%82alno\%C 5\%9Bci\%20sp\%C3\%B3\%C5\%82ki\%20za\%20rok\%20obrotowy\%202012.pdf

Verde, S. (2008). Everybody merges with somebody-The wave of M\&As in the energy industry and the EU merger policy. Energy Policy, 36, 1126. 